\title{
Analisis Berpikir Siswa dalam Memecahkan Masalah Dimensi Tiga Berdasarkan Van Hiele
}

\author{
Author: \\ Amaliyatul Indah ${ }^{1}$ \\ Erfan Yudianto ${ }^{2}$ \\ Titik Sugiarti ${ }^{3}$ \\ Tri Murniawati ${ }^{4}$ \\ Affiliation: \\ ${ }^{1,2,3}$ University of Jember, East \\ Java, Indonesia \\ ${ }^{4}$ SMK Negeri 2 Jember, East \\ Java, Indonesia

\section{Corresponding author:} \\ Amaliyatul Indah, \\ amaliyatulindah@gmail.com
}

\section{Dates:}

Received: 7/6/2021

Accepted: $1 / 7 / 2021$

Published: 9/7/2021

\begin{abstract}
Abstrak. Pada pembelajaran matematika, masih diperlukan adanya inovasi untuk membuat matematika lebih mudah dipahami oleh siswa, khususnya pada bidang geometri. Hal tersebut menjadi menarik ketika dikaji dan dikaitkan dengan level berpikir geometri van Hiele yang dimodifikasi dengan langkahlangkah pemecahan masalah Polya. Penelitian ini bertujuan untuk mengetahui proses berpikir siswa SMK jurusan Teknik Desain Pemodelan dan Informasi Bangunan dalam memecahkan masalah dimensi tiga. Jenis penelitian adalah penelitian deskriptif kualitatif. Subjek penelitian yaitu siswa level pra visualisasi, visualisasi, analisis, dan deduksi informal. Subjek penelitian mengerjakan tes masalah dimensi tiga dan dilakukan wawancara. Hasil yang diperoleh adalah siswa level pravisualisasi memenuhi beberapa indikator pada level visualisasi, siswa level visualisasi dan analisis memenuhi semua indikator pada levelnya masing-masing, sedangkan siswa level deduksi informal tidak mampu memenuhi satu indikator pada saat melaksanakan rencana yaitu mempunyai cara lain dalam memecahkan masalah. Hal ini terlihat dari hasil pemecahan masalah yang diberikan dan wawancara yang dilakukan terhadap subjek penelitian.
\end{abstract}

Kata kunci: Berpikir, Pemecahan Masalah, Dimensi Tiga, Van Hiele
Abstract. In learning mathematics, innovation is still needed to make mathematics more easily understood by students, especially in the field of geometry. This becomes interesting when examined and is associated with van Hiele's level of geometrical thinking which is modified by Polya's problem solving steps. This study aims to determine the thought process of vocational students majoring in Modeling Design Engineering and Building Information in solving three dimensional problems. This type of research is a qualitative descriptive study. The research subjects are students of pre-visualization, visualization, analysis, and informal deduction level. The research subjects worked on the three dimensional problem test and were interviewed. The results obtained are pre-visualization level students fulfilling several indicators at the visualization level, students at the visualization and analysis level meet all indicators at their respective levels, while informal deduction level students are unable to meet one indicator when implementing a plan that is having another way of solving problems. This can be seen from the results of problem solving given and interviews conducted on research subjects.

Keywords: Thinking, Problem Solving, Three Dimensions, van Hiele

\section{J0M G L combate International License. \\ Read online: \\ https://jurnal.unej.ac.id/index.php/JOMEAL/index or scan barcode beside.}

This work is licensed under a Creative Commons Attribution-ShareAlike 4.0

\section{How to cite this article:}

Indah, A., Yudianto, E., Sugiarti, T., \& Murniawati, T. (2021). Analisis Berpikir Siswa dalam Memecahkan Masalah Dimensi Tiga Berdasarkan Van Hiele. Journal of Mathematics Education and Learning, 1(2), 137148. Retrieved from https://jurnal.unej.ac.id/index.php/JOMEAL/article/view/24323 


\section{Pendahuluan}

Hepytriati (2014) menyatakan bahwa berpikir merupakan proses mencari pemahaman terhadap berbagai macam ide dan membuat keputusan serta menyelesaikan masalah dengan membuat refleksi dan metakognisi terhadap proses yang dialami. Berpikir geometri merupakan suatu proses mencari ide berdasarkan pemahaman siswa terkait materi geometri meliputi proses pencarian solusi dari permasalahan geometri yang sedang siswa hadapi. Menurut Budiman (2015) kemampuan berpikir geometri ini umumnya diukur berdasarkan level berpikir geometri model van Hiele. Berpikir geometri menurut teori van Hiele memiliki 4 level/tingkatan berpikir yaitu level 0 (visualisasi), level 1 (analisis), level 2 (deduksi informal), level 3 (deduksi), dan level 4 (rigor). Siswa dikatakan berada pada level visualisasi ketika siswa mampu mengenal bangun-bangun geometri, siswa dikatakan berada pada level analisis ketika siswa mampu mengenal sifat-sifat suatu bangun geometri, siswa dikatakan berada pada level deduksi informal ketika siswa mampu melihat hubungan sifat-sifat dalam satu bangun, siswa dikatakan berada pada level deduksi ketika siswa mampu membuktikan suatu pernyataan geometri, dan siswa dikatakan berada pada level rigor ketika siswa mampu memahami perbedaan geometri Euclides dan geometri non-Euclides (Sunardi \& Yudianto, 2015). Pada proses pemecahan permasalahan, siswa sering menggunakan langkah-langkah yaitu memahami masalah, menyusun rencana, melaksanakan rencana, dan memeriksa kembali. Oleh karena itu, analisis berpikir siswa dalam penelitian ini akan dijabarkan berdasarkan teori van Hiele dan berdasarkan pada langkah pemecahan masalah yang dikemukakan oleh Polya (1973).

Masalah adalah suatu situasi atau pertanyaan yang dihadapi seorang individu atau kelompok ketika mereka tidak mempunyai aturan atau prosedur tertentu yang segera dapat digunakan untuk menemukan jawabannya (Siswono \& Tatang, 2008). Pemecahan masalah sebagai suatu proses atau langkah dimana pemecah masalah harus menemukan hubungan antara pengalaman masa lalu (skema) dan masalah yang dihadapi dan kemudian bertindak berdasarkan sebuah solusi (Kirkley, 2003). Salah satu teori tentang pemecahan masalah dikemukakan oleh Polya dengan langkah-langkah yaitu memahami masalah, meyusun rencana, melaksanakan rencana, dan memeriksa kembali (Polya, 1973).

Dimensi tiga merupakan salah satu materi geometri yang terdapat dalam ilmu matematika. Materi dimensi tiga biasanya dipelajari pada jenjang SMA/MA/SMK. Pada materi dimensi tiga dipelajari jarak titik ke titik, jarak titik ke garis, dan jarak titik ke bidang (Kemendikbud, 2018). Definisi titik adalah suatu unsur yang tak terdefinisi (Rawuh, 2009). Definisi garid adalah himpunan titik-titik yang mengandung paling sedikit dua titik atau dua titik yang berlainan terkandung dalam tepat satu garis (Rawuh, 2009). Definisi bidang adalah himpunan titik-titik yang mengandung paling sedikit tiga titik yang tidak terkandung dalam satu garis atau tiga titik berlainan yang tak segaris terkandung dalam satu dan tidak lebih dari satu bidang (Rawuh, 2009).

Berdasarkan penelitian sebelumnya yang dilakukan oleh Sunardi (2000) menunjukkan bahwa model pembelajaran geometri berbasis teori van Hiele dapat meningkatkan tingkat berpikir geometri siswa. Penelitian oleh Firmansyah, dkk (2019) menunjukkan bahwa siswa visualisasi dapat menyelesaikan masalah di tingkat analisis. Penelitian Fitriyani, dkk (2018) juga menyatakan bahwa sebagian siswa masih pada level analisis. Namun, pada penelitian Utami, dkk (2016) telah menemukan siswa level deduksi pada jenjang SMP dan mampu menjawab permasalahan yang diberikan serta dapat menyusun bukti, tidak hanya sekedar menerima bukti. Penelitian lain yang dilakukan oleh Marlina (2013) menunjukkan bahwa penerapan langkah Polya dapat meningkatkan hasil belajar siswa. Selain itu, penelitian yang dilakukan oleh Sunardi dan Yudianto (2015) menyatakan bahwa sebagian besar siswa di sekolah masih berada di tiga level pertama berpikir siswa 
menurut teori van Hiele. Pada penelitian (Sholihah \& Afriansyah, 2017) menyatakan bahwa ketercapaian siswa pada proses pemecahan masalah geometri berdasarkan tahapan berpikir Van Hiele paling banyak adalah pada tahap 0 (visualisasi). Dengan demikian, tujuan penelitian ini adalah untuk menganalisis berpikir siswa SMK terutama jurusan Teknik Desain Pemodelan dan Informasi Bangunan (DPIB) dalam memecahkan masalah dimensi tiga.

\section{Metode Penelitian}

Penelitian ini merupakan penelitian deskriptif kualitatif. Menurut Sukardi (2011) pengertian penelitian deskriptif adalah suatu penelitian dengan pengumpulan data dilakukan untuk menguji hipotesis yang sesuai keadaan serta melaporkannya dalam bentuk apa adanya. Pengertian penelitian kualitatif dalam Moleong (2012) adalah suatu penelitian yang bermaksud untuk memahami fenomena tentang apa yang dialami oleh subjek penelitian, misalnya perilaku, presepsi, motivasi, tindakan, dan lain-lain. Metode pengumpulan data yang digunakan adalah metode tes dan metode wawancara. Metode tes adalah serangkaian pertanyaan, latihan atau alat untuk mengukur kemampuan individu atau kelompok baik pengetahuan, keterampilan, kemampuan atau bakat yang dimiliki (Arikunto, 2006). Metode tes dalam penelitian ini dilakukan sebanyak dua kali yaitu tes tingkat kemampuan berpikir geometri menurut van Hiele dan tes masalah dimensi tiga. Tes tingkat kemampuan berpikir geometri menurut van Hiele tidak perlu adanya validasi dikarenakan diambil dari penelitian Sunardi pada tahun 2000, sedangkan tes masalah dimensi tiga dilakukan validasi dan telah dinyatakan valid. Subjek tes tingkat kemampuan berpikir geometri van Hiele dan tes masalah dimensi tiga terdiri dari 34 siswa kelas XI DPIB 1 dan 36 siswa kelas XI DPIB 2 SMK Negeri 2 Jember. Hasil tes tingkat berpikir geometri siswa dikategorikan sesuai level van Hiele yaitu dengan pedoman kriteria penilaian tes tingkat kemampuan berpikir geometri (Usikin, 1982). Pedoman itu menyatakan bahwa siswa dikatakan mencapai level tertentu pada level van Hiele apabila siswa tersebut mampu menjawab minimal 3 dari 5 soal yang ada pada setiap level tertentu dengan benar. Tahap berikutnya yaitu siswa mengerjakan tes masalah dimensi tiga yang terdiri dari 3 soal esai yaitu jarak titik ke titik, jarak titik ke garis, dan jarak titik ke bidang. Setelah itu, dilakukan metode wawancara dengan tujuan memperkuat hasil dari metode tes. Pedoman wawancara juga divalidasi dan dinyatakan valid. Metode wawancara adalah sebuah dialog yang dilakukan oleh pewancara untuk memperoleh informasi dari sumber (Arikunto, 2006). Wawancara yang dilakukan dalam penelitian ini menggunakan teknik snowball sampling. Sugiyono (2016) menyatakan bahwa teknik snowball sampling adalah teknik pengambilan sampel sumber data yang pada awalnya jumlahnya sedikit tersebut belum mampu memberikan data yang lengkap, maka harus mencari orang lain yang dapat digunakan sebagai sumber data. Teknik snowball sampling dilakukan pada 7 orang siswa dalam menentukan siswa level pra visualisasi, visualisasi, dan analisis. Untuk siswa level deduksi informal tidak dilakukan teknik snowball sampling karena hanya ditemukan 1 siswa pada level tersebut.

\section{Hasil dan Pembahasan}

Hasil tes tingkat kemampuan berpikir geometri van Hiele dalam penelitian ini ditemukan siswa level pra visualisasi, level visualisasi, level analisis, dan level deduksi informal dengan persentase berturut-turut adalah 32,8\% (23 siswa), 44,3\% (31 siswa), 12,9\% (9 siswa), dan 1,4\% (1 siswa). Siswa untuk kategori deduksi dan rigor tidak dapat ditemukan dan sebanyak 8,6\% (6 siswa) tidak dapat dikategorikan dalam level van Hiele karena tidak mengikuti tes tingkat kemampuan berpikir geometri 
van Hiele. Analisis tes tingkat kemampuan berpikir geometri van Hiele yang telah dikerjakan siswa dengan benar dapat dilihat pada Tabel 1 .

Tabel 1. Analisis Tes Tingkat Berpikir Geometri Siswa menurut van Hiele

\begin{tabular}{|l|c|c|c|c|c|}
\hline \multicolumn{1}{|c|}{ Level } & Nomor & Nomor & Nomor & Nomor & Nomor \\
& Soal & Soal & soal & soal & soal \\
& $1-5$ & $6-10$ & $11-15$ & $16-20$ & $21-25$ \\
\hline Pra Visualisasi (S1) & 1 soal & 3 soal & 2 soal & 1 soal & 1 soal \\
\hline Visualisasi (S2) & 3 soal & 2 soal & 0 soal & 1 soal & 2 soal \\
\hline Analisis (S3) & 4 soal & 3 soal & 0 soal & 1 soal & 1 soal \\
\hline Deduksi Informal (S4) & 3 soal & 4 soal & 3 soal & 1 soal & 1 soal \\
\hline
\end{tabular}

Subjek penelitian diberikan tes masalah dimensi tiga dan dilakukan wawancara. Hasil dalam penelitian ini berupa uraian proses berpikir geometri siswa SMK jurusan Teknik Desain Pemodelan dan Informasi Bangunan level pra visualisasi, visualisasi, analisis, dan deduksi informal dalam memecahkan masalah dimensi tiga. Proses berpikir siswa dapat diketahui melalui hasil pemecahan masalah dimensi tiga yang diberikan dan hasil wawancara. Hasil ketercapaian indikator siswa level pra visualisasi, visualisasi, analisis, dan deduksi informal dalam penelitian ini dapat dilihat pada Tabel 2 .

Tabel 2. Hasil Ketercapaian Indikator dalam Memecahkan Masalah Dimensi Tiga

\begin{tabular}{|c|c|c|c|c|c|}
\hline $\begin{array}{c}\text { Langkah- } \\
\text { Langkah Polya }\end{array}$ & Indikator & S1 & S2 & S3 & S4 \\
\hline \multirow[t]{4}{*}{$\begin{array}{l}\text { Memahami } \\
\text { masalah }\end{array}$} & $\begin{array}{l}\text { Membaca permasalahan yang diberikan } \\
\text { hingga paham }\end{array}$ & $\checkmark$ & $\checkmark$ & $\checkmark$ & $\checkmark$ \\
\hline & $\begin{array}{l}\text { Mengidentifikasi hal-hal yang diketahui, } \\
\text { ditanyakan, dan syarat-syarat dalam } \\
\text { permasalahan }\end{array}$ & - & $\checkmark$ & $\checkmark$ & $\checkmark$ \\
\hline & Membuat gambar dari permasalahan & $\checkmark$ & $\checkmark$ & $\checkmark$ & $\checkmark$ \\
\hline & $\begin{array}{l}\text { Memprediksi pengetahuan yang akan } \\
\text { digunakan untuk menyelesaikan } \\
\text { permasalahan }\end{array}$ & - & - & $\checkmark$ & $\checkmark$ \\
\hline \multirow[t]{4}{*}{$\begin{array}{l}\text { Menyusun } \\
\text { rencana }\end{array}$} & $\begin{array}{l}\text { Menentukan rencana yang digunakan } \\
\text { untuk memecahkan masalah melalui } \\
\text { gambar }\end{array}$ & - & $\checkmark$ & - & - \\
\hline & $\begin{array}{l}\text { Menentukan rencana yang digunakan } \\
\text { untuk memecahkan masalah dengan } \\
\text { melibatkan sifat-sifat bangun }\end{array}$ & - & - & $\checkmark$ & - \\
\hline & $\begin{array}{l}\text { Menentukan rencana yang digunakan } \\
\text { untuk memecahkan masalah dengan } \\
\text { melibatkan pengetahuan yang telah } \\
\text { didapatkan }\end{array}$ & - & - & - & $\checkmark$ \\
\hline & $\begin{array}{l}\text { Memilih cara atau strategi yang tepat } \\
\text { melibatkan informasi yang diketahui } \\
\text { pada permasalahan }\end{array}$ & - & $\checkmark$ & $\checkmark$ & $\checkmark$ \\
\hline \multirow[t]{3}{*}{$\begin{array}{l}\text { Melaksanakan } \\
\text { rencana }\end{array}$} & $\begin{array}{l}\text { Melibatkan pengetahuan yang didapat } \\
\text { sebelumnya dengan tepat dalam } \\
\text { menyelesaikan masalah }\end{array}$ & - & - & $\checkmark$ & $\checkmark$ \\
\hline & $\begin{array}{l}\text { Mengkontruks proses penyelesaian } \\
\text { masalah }\end{array}$ & - & $\checkmark$ & $\checkmark$ & $\checkmark$ \\
\hline & $\begin{array}{l}\text { Pada saat menyelesaikan permasalahan, } \\
\text { siswa berpikir mempunyai cara lain } \\
\text { untuk menyelesaikan permasalahan }\end{array}$ & - & - & - & - \\
\hline
\end{tabular}




\begin{tabular}{|l|l|c|c|c|c|}
\hline $\begin{array}{c}\text { Langkah- } \\
\text { Langkah Polya }\end{array}$ & \multicolumn{1}{|c|}{ Indikator } & S1 & S2 & S3 & S4 \\
\hline & $\begin{array}{l}\text { Mengerjakan dan menjelaskan jawaban } \\
\text { penyelesaian secara runtut }\end{array}$ & $\checkmark$ & $\checkmark$ & $\checkmark$ & $\checkmark$ \\
\cline { 2 - 6 } & $\begin{array}{l}\text { Memperoleh hasil dari tujuan masalah } \\
\text { yang diberikan }\end{array}$ & $\checkmark$ & $\checkmark$ & $\checkmark$ & $\checkmark$ \\
\hline $\begin{array}{l}\text { Memeriksa } \\
\text { kembali }\end{array}$ & $\begin{array}{l}\text { Mengoreksi kembali jawaban yang } \\
\text { didapatkan }\end{array}$ & $\checkmark$ & $\checkmark$ & $\checkmark$ & $\checkmark$ \\
\cline { 2 - 6 } & $\begin{array}{l}\text { Menuliskan dan menjelaskan } \\
\text { kesimpulan dari permasalahan dengan } \\
\text { tepat }\end{array}$ & - & - & - & $\checkmark$ \\
\hline
\end{tabular}

Berdasarkan hasil yang diperoleh dalam penelitian ini menyatakan bahwa siswa dapat digolongkan menjadi level pra visualisasi, visualisasi (level 0), analisis (level 1), dan deduksi informal (level 2). Hal tersebut sesuai dengan hasil penelitian sebelumnya yang menyatakan bahwa sebagian besar siswa di sekolah masih berada di tiga level pertama berpikir siswa menurut teori van Hiele yaitu level visualisasi, level analisis, dan level deduksi informal (Sunardi \& Yudianto, 2015).

Penelitian ini membuktikan bahwa siswa level pra visualisasi mampu memecahkan masalah dimensi tiga, namun hanya memenuhi lima dari sembilan indikator pada level visualisasi. Hal ini sesuai dengan teori yang disampaikan Clements dan Battista (1992) yang menyatakan bahwa siswa pada level pra visualisasi hanya memperhatikan sebagian dari karakteristik level visualisasi (Clements \& Battista, 1992). Proses berpikir siswa dalam level pra visualisasi tergambar dalam hasil ketercapaian indikator dan wawancara. Siswa level pra visualisasi memenuhi dua dari tiga indikator pada langkah pertama yaitu langkah memahami masalah. Indikator pertama adalah membaca permasalahan yang diberikan hingga paham, subjek dapat memahami permasalahan dengan membaca permasalahan sekitar tiga kali dengan alasan agar lebih memahami. Indikator kedua yaitu mengidentifikasi hal-hal yang diketahui, ditanyakan, dan syarat-syarat dalam permasalahan, subjek tidak menuliskan atau menyebutkan dengan lancar hal-hal yang diketahui dan ditanyakan beserta syarat-syarat dalam permasalahan. Indikator ketiga adalah membuat gambar dari permasalahan, subjek mengatakan bahwa permasalahan yang diberikan dapat diselesaikan dengan membuat gambar dari permasalahan terlebih dahulu. Hasil ini kurang sesuai dengan teori pemecahan masalah Polya pada level visualisasi yang menyatakan bahwa siswa dikatakan memahami suatu permasalahan ketika siswa mampu mengidentifikasi hal-hal yang diketahui dan membuat gambar dari permasalahan (Polya, 1973). Oleh karena itu, siswa level pra visualisasi belum mampu melewati langkah memahami masalah dalam memecahkan masalah dimensi tiga. Langkah kedua yaitu menyusun rencana, siswa level visualisasi tidak memenuhi satupun indikator. Indikator pertama adalah menentukan rencana yang digunakan untuk memecahkan masalah melalui gambar, indikator ini tidak dipenuhi subjek namun subjek dapat membuat gambar dari permasalahan tetapi tidak mampu merencakan hal-hal yang dilakukan untuk memecahkan masalah. Indikator kedua adalah memilih cara yang tepat melibatkan informasi yang diketahui pada permasalahan, indikator ini juga tidak dipenuhi subjek. Hal itu tidak sesuai dengan teori pemecahan masalah Polya pada level visualisasi yang menyatakan bahwa siswa dikatakan mampu menyusun rencana untuk memecahkan masalah ketika siswa mampu menentukan rencana dan memilih strategi sesuai pengetahuan yang telah didapatkan sebelumnya (Polya, 1973). Oleh karena itu, siswa level pra visualisasi belum mampu melewati langkah menyusun rencana dalam memecahkan masalah dimensi tiga. Langkah ketiga yaitu melaksanakan rencana, siswa level visualisasi memenuhi dua dari tiga indikator pada level visualisasi. 
Indikator pertama adalah mengkonstruks proses penyelesaian masalah, subjek tidak dapat memenuhi indikator. Indikator kedua adalah mengerjakan dan menjelaskan jawaban penyelesaian secara runtut, subjek dengan menjelaskan kembali penyelesaian yang telah dikerjakan dengan sangat baik dan benar. Indikator ketiga adalah memperoleh hasil dari tujuan masalah yang diberikan, subjek dikatakan memenuhi indikator ini karena telah memperoleh jawaban yang sesuai dengan permasalahan yang diberikan. Analisis hasil ini kurang sesuai dengan teori pemecahan masalah Polya pada level visualisasi yang menyatakan bahwa siswa dikatakan mampu melaksanakan rencana ketika siswa mampu menjalankan rencana yang telah dibuat serta mengerjakan dan menjelaskan secara runtut penyelesaian dari permasalahan (Polya, 1973). Oleh karena itu, siswa pra visualisasi belum mampu melewati langkah melaksanakan rencana dalam memecahkan masalah dimensi tiga. Langkah akhir yaitu memeriksa kembali. Pada langkah ini siswa level pra visualisasi memenuhi indikator pada level visualisasi yaitu mengoreksi kembali jawaban yang didapatkan, subjek menyatakan bahwa dalam memeriksa kembali yang dilakukan adalah dengan membaca permasalahan dan menyocokkan kembali dengan jawaban yang didapatkan. Hal tersebut sesuai dengan teori pemecahan masalah Polya pada level visualisasi bahwa siswa dikatakan mampu memeriksa kembali ketika siswa meneliti kembali penyelesaian (Polya, 1973). Oleh karena itu, siswa level pra visualisasi dikatakan mampu melewati langkah memeriksa kembali dalam memecahkan masalah dimensi tiga.

Selain itu, penelitian ini dapat membuktikan bahwa siswa level visualisasi mampu memecahkan masalah dimensi tiga. Proses berpikir siswa dalam level visualisasi tergambar dalam hasil ketercapaian indikator dan wawancara. Siswa level visualisasi memenuhi semua indikator pada langkah pertama yaitu langkah memahami masalah. Indikator pertama adalah membaca permasalahan yang diberikan hingga paham, subjek dapat memahami permasalahan dengan membaca permasalahan sekitar empat hingga lima kali dengan alasan agar lebih memahami. Indikator kedua yaitu mengidentifikasi hal-hal yang diketahui, ditanyakan, dan syarat-syarat dalam permasalahan, subjek menyebutkan dengan lancar hal-hal yang diketahui dan ditanyakan beserta syarat-syarat dalam permasalahan walaupun tidak secara lengkap. Indikator ketiga adalah membuat gambar dari permasalahan, subjek mengatakan bahwa permasalahan yang diberikan dapat diselesaikan dengan membuat gambar dari permasalahan terlebih dahulu. Hasil ini sesuai dengan teori pemecahan masalah Polya pada level visualisasi yang menyatakan bahwa siswa dikatakan memahami suatu permasalahan ketika siswa mampu mengidentifikasi hal-hal yang diketahui dan membuat gambar dari permasalahan (Polya, 1973). Oleh karena itu, siswa level visualisasi dikatakan dapat melewati langkah memahami masalah dalam memecahkan masalah dimensi tiga. Langkah kedua yaitu menyusun rencana, siswa level visualisasi memenuhi semua indikator. Indikator pertama adalah menentukan rencana yang digunakan untuk memecahkan masalah melalui gambar, indikator ini telah dipenuhi subjek dikarenakan subjek dapat membuat gambar dari permasalahan dan mampu merencakan hal-hal yang dilakukan untuk memecahkan masalah. Indikator kedua adalah memilih cara yang tepat melibatkan informasi yang diketahui pada permasalahan, indikator ini telah dipenuhi subjek yang menyebutkan bahwa subjek memecahkan masalah dengan menggunakan rumus segitiga yang sebenarnya adalah rumus Pythagoras karena subjek tidak mengetahui bahwa rumus yang digunakan disebut dengan rumus Pythagoras. Hal itu sesuai dengan teori pemecahan masalah Polya pada level visualisasi yang menyatakan bahwa siswa dikatakan mampu menyusun rencana untuk memecahkan masalah ketika siswa mampu menentukan rencana dan memilih strategi sesuai pengetahuan yang telah didapatkan sebelumnya (Polya, 1973). Oleh karena itu, siswa level visualisasi dikatakan dapat melewati langkah menyusun rencana dalam memecahkan masalah dimensi tiga. 
Melaksanakan rencana adalah langkah ketiga pada tahapan pemecahan masalah Polya. Pada langkah ini siswa level visualisasi memenuhi semua indikator. Indikator pertama adalah mengkonstruks proses penyelesaian masalah, subjek dapat memenuhi indikator ini karena dapat menunjukkan halhal yang akan dilakukan dalam memecahkan masalah secara detail. Indikator kedua adalah mengerjakan dan menjelaskan jawaban penyelesaian secara runtut, subjek dengan menjelaskan kembali penyelesaian yang telah dikerjakan dengan sangat baik dan benar. Indikator ketiga adalah memperoleh hasil dari tujuan masalah yang diberikan, subjek dikatakan memenuhi indikator ini karena telah memperoleh jawaban yang sesuai dengan permasalahan yang diberikan. Analisis hasil ini sesuai dengan teori pemecahan masalah Polya pada level visualisasi yang menyatakan bahwa siswa dikatakan mampu melaksanakan rencana ketika siswa mampu menjalankan rencana yang telah dibuat serta mengerjakan dan menjelaskan secara runtut penyelesaian dari permasalahan (Polya, 1973). Oleh karena itu, siswa visualisasi dikatakan dapat melewati langkah melaksanakan rencana dalam memecahkan masalah dimensi tiga. Langkah akhir yaitu memeriksa kembali. Pada langkah ini siswa level visualisasi memenuhi indikator pada level visualisasi yaitu mengoreksi kembali jawaban yang didapatkan, subjek menyatakan bahwa dalam memeriksa kembali yang dilakukan adalah dengan membaca permasalahan dan menyocokkan kembali dengan jawaban yang didapatkan. Hal tersebut sesuai dengan teori pemecahan masalah Polya pada level visualisasi bahwa siswa dikatakan mampu memeriksa kembali ketika siswa meneliti kembali penyelesaian (Polya, 1973). Oleh karena itu, siswa level visualisasi dikatakan dapat melewati langkah memeriksa kembali dalam memecahkan masalah dimensi tiga.

Siswa level analisis juga dapat dibuktikan mampu menyelesaikan masalah dimensi tiga dalam penelitian ini. Proses berpikir siswa dalam level analisis tergambar dalam hasil ketercapaian indikator dan wawancara. Siswa level analisis memenuhi semua indikator pada langkah pertama yaitu langkah memahami masalah. Indikator pertama adalah membaca permasalahan yang diberikan hingga paham, subjek dapat memahami permasalahan dengan membaca permasalahan sekitar dua kali dengan alasan agar lebih memahami. Indikator kedua yaitu mengidentifikasi hal-hal yang diketahui, ditanyakan, dan syarat-syarat dalam permasalahan, subjek menyebutkan dengan lancar hal-hal yang diketahui dan ditanyakan beserta syarat-syarat dalam permasalahan. Indikator ketiga adalah membuat gambar dari permasalahan, subjek mengatakan bahwa permasalahan yang diberikan dapat diselesaikan dengan membuat gambar dari permasalahan terlebih dahulu. Indikator keempat yaitu memprediksi pengetahuan yang akan digunakan untuk menyelesaikan permasalahan, indikator ini dipenuhi karena subjek dapat menghubungkan informasi yang telah didapatkan dengan memprediksi pengetahuan yang digunakan. Hasil ini sesuai dengan teori pemecahan masalah Polya pada level analisis yang menyatakan bahwa siswa dikatakan memahami suatu permasalahan ketika siswa mampu mengidentifikasi hal-hal yang diketahui, membuat gambar dari permasalahan, dan memprediksi pengetahuan yang akan digunakan untuk menyelesaikan permasalahan (Polya, 1973). Oleh karena itu, siswa level analisis dikatakan dapat melewati langkah memahami masalah dalam memecahkan masalah dimensi tiga. Langkah kedua yaitu menyusun rencana, siswa level analisis memenuhi semua indikator. Indikator pertama adalah menentukan rencana yang digunakan untuk memecahkan masalah dengan melibatkan sifat-sifat bangun, indikator ini telah dipenuhi subjek dikarenakan subjek dapat menemukan beberapa hasil dengan melihat siat-sifat bangun dari permasalahan. Indikator kedua adalah memilih cara yang tepat melibatkan informasi yang diketahui pada permasalahan, indikator ini telah dipenuhi subjek yang menyebutkan bahwa subjek memecahkan masalah dengan menggunakan rumus Phytagoras sesuai dengan pengetahuan yang telah didapatkan sebelumnya. Hal 
itu sesuai dengan teori pemecahan masalah Polya pada level analisis yang menyatakan bahwa siswa dikatakan mampu menyusun rencana untuk memecahkan masalah ketika siswa mampu menentukan rencana dan memilih strategi sesuai pengetahuan yang telah didapatkan sebelumnya (Polya, 1973). Oleh karena itu, siswa level analisis dikatakan dapat melewati langkah menyusun rencana dalam memecahkan masalah dimensi tiga. Melaksanakan rencana adalah langkah ketiga pada tahapan pemecahan masalah Polya. Pada langkah ini siswa level analisis memenuhi semua indikator. Indikator pertama adalah melibatkan pengetahuan yang didapatkan sebelumnya dengan tepat dalam menyelesaikan masalah, subjek dikatakan memenuhi indikator ini karena subjek menyebutkan dan menjelaskan bahwa penyelesaian menggunakan rumus Phytagoras. Indikator kedua adalah mengkonstruks proses penyelesaian masalah, subjek dapat memenuhi indikator ini karena dapat menunjukkan hal-hal yang akan dilakukan dalam memecahkan masalah secara detail. Indikator ketiga adalah mengerjakan dan menjelaskan jawaban penyelesaian secara runtut, subjek dengan menjelaskan kembali penyelesaian yang telah dikerjakan dengan sangat baik dan benar. Indikator keempat adalah memperoleh hasil dari tujuan masalah yang diberikan, subjek dikatakan memenuhi indikator ini karena telah memperoleh jawaban yang sesuai dengan permasalahan yang diberikan. Analisis hasil ini sesuai dengan teori pemecahan masalah Polya pada level analisis yang menyatakan bahwa siswa dikatakan mampu melaksanakan rencana ketika siswa mampu menjalankan rencana yang telah dibuat serta mengerjakan dan menjelaskan secara runtut penyelesaian dari permasalahan (Polya, 1973). Oleh karena itu, siswa analisis dikatakan dapat melewati langkah melaksanakan rencana dalam memecahkan masalah dimensi tiga. Langkah akhir yaitu memeriksa kembali. Pada langkah ini siswa level analisis memenuhi indikator pada level analisis yaitu mengoreksi kembali jawaban yang didapatkan, subjek menyatakan bahwa dalam memeriksa kembali yang dilakukan adalah dengan membaca permasalahan dan menyocokkan kembali dengan jawaban yang didapatkan. Hal tersebut sesuai dengan teori pemecahan masalah Polya pada level analisis bahwa siswa dikatakan mampu memeriksa kembali ketika siswa meneliti kembali penyelesaian (Polya, 1973). Oleh karena itu, siswa level analisis dikatakan dapat melewati langkah memeriksa kembali dalam memecahkan masalah dimensi tiga.

Penelitian ini juga dapat membuktikan bahwa siswa level deduksi informal mampu memecahkan masalah dimensi tiga. Proses berpikir siswa dalam level deduksi informal tergambar dalam hasil ketercapaian indikator dan wawancara. Siswa level deduksi informal memenuhi semua indikator pada langkah pertama yaitu langkah memahami masalah. Indikator pertama adalah membaca permasalahan yang diberikan hingga paham, subjek dapat memahami permasalahan dengan membaca permasalahan sebanyak satu kali dengan alasan langsung menuliskan hal-hal yang diketahui, ditanyakan serta membuat gambar dari permasalahan yang telah dipahami. Hasil tersebut telah menyatakan bahwa subjek juga memenuhi indikator kedua yaitu mengidentifikasi hal-hal yang diketahui, ditanyakan, dan syarat-syarat dalam permasalahan serta memenuhi indikator ketiga yaitu membuat gambar dari permasalahan. Indikator keempat yaitu memprediksi pengetahuan yang akan digunakan untuk menyelesaikan permasalahan, indikator ini dipenuhi karena subjek dapat menghubungkan informasi yang telah didapatkan dengan memprediksi pengetahuan yang digunakan. Hasil ini sesuai dengan teori pemecahan masalah Polya pada level deduksi informal yang menyatakan bahwa siswa dikatakan memahami suatu permasalahan ketika siswa mampu mengidentifikasi hal-hal yang diketahui, membuat gambar dari permasalahan, dan memprediksi pengetahuan yang akan digunakan untuk menyelesaikan permasalahan (Polya, 1973). Oleh karena itu, siswa level deduksi informal dikatakan dapat melewati langkah memahami masalah dalam memecahkan masalah dimensi 
tiga. Langkah kedua yaitu menyusun rencana, siswa level deduksi informal memenuhi semua indikator. Indikator pertama adalah menentukan rencana yang digunakan untuk memecahkan masalah dengan melibatkan pengetahuan yang telah didapatkan, indikator ini telah dipenuhi subjek dikarenakan subjek telah memprediksi pengetahuan pada langkah memahami masalah. Indikator kedua adalah memilih cara yang tepat melibatkan informasi yang diketahui pada permasalahan, indikator ini telah dipenuhi subjek yang menyebutkan bahwa subjek memecahkan masalah dengan menggunakan rumus Pythagoras sesuai dengan pengetahuan yang telah didapatkan sebelumnya. Hal itu sesuai dengan teori pemecahan masalah Polya pada level deduksi informal yang menyatakan bahwa siswa dikatakan mampu menyusun rencana untuk memecahkan masalah ketika siswa mampu menentukan rencana dan memilih strategi sesuai pengetahuan yang telah didapatkan sebelumnya (Polya, 1973). Oleh karena itu, siswa level deduksi informal dikatakan dapat melewati langkah menyusun rencana dalam memecahkan masalah dimensi tiga. Melaksanakan rencana adalah langkah ketiga pada tahapan pemecahan masalah Polya. Pada langkah ini siswa level deduksi informal memenuhi empat dari lima indikator. Indikator pertama adalah melibatkan pengetahuan yang didapatkan sebelumnya dengan tepat dalam menyelesaikan masalah, subjek dikatakan memenuhi indikator ini karena subjek menyebutkan dan menjelaskan bahwa penyelesaian menggunakan rumus Pythagoras. Indikator kedua adalah mengkonstruks proses penyelesaian masalah, subjek dapat memenuhi indikator ini karena dapat menunjukkan hal-hal yang akan dilakukan dalam memecahkan masalah secara detail. Indikator ketiga adalah mempunyai cara lain untuk menyelesaikan permasalahan, pada indikator ini subjek tidak memenuhi indikator dikarenakan subjek menjawab bahwa tidak mempunyai cara lain dalam memecahkan permasalahan dan hanya dapat menggunakan rumus Pythagoras saja. Indikator keempat adalah mengerjakan dan menjelaskan jawaban penyelesaian secara runtut, subjek dengan menjelaskan kembali penyelesaian yang telah dikerjakan dengan sangat baik dan benar. Indikator kelima adalah memperoleh hasil dari tujuan masalah yang diberikan, subjek dikatakan memenuhi indikator ini karena telah memperoleh jawaban yang sesuai dengan permasalahan yang diberikan. Analisis hasil ini sesuai dengan teori pemecahan masalah Polya pada level deduksi informal yang menyatakan bahwa siswa dikatakan mampu melaksanakan rencana ketika siswa mampu menjalankan rencana yang telah dibuat serta mengerjakan dan menjelaskan secara runtut penyelesaian dari permasalahan (Polya, 1973). Oleh karena itu, siswa level deduksi informal dikatakan dapat melewati langkah melaksanakan rencana dalam memecahkan masalah dimensi tiga meskipun tidak memenuhi satu indikator pada levelnya karena subjek mampu menjalankan rencana dan menjelaskan penyelesaian secara runtut. Langkah akhir yaitu memeriksa kembali. Pada langkah ini siswa level deduksi informal memenuhi semua indikator. Indikator pertama adalah mengoreksi kembali jawaban yang didapatkan, subjek menyatakan bahwa dalam memeriksa kembali yang dilakukan adalah dengan membaca permasalahan dan menghitung kembali dari awal pekerjaan hingga selesai. Indikator kedua yaitu menuliskan dan menjelaskan kesimpulan dari permasalahan dengan tepat, subjek memang tidak menuliskan kesimpulan, namun mampu menjelaskan kesimpulan yan telah didapaatkan. Hal tersebut sesuai dengan teori pemecahan masalah Polya pada level deduksi informal bahwa siswa dikatakan mampu memeriksa kembali ketika siswa meneliti kembali penyelesaian dan membuat kesimpulan (Polya, 1973). Oleh karena itu, siswa level deduksi informal dikatakan dapat melewati langkah memeriksa kembali dalam memecahkan masalah dimensi tiga. 


\section{Kesimpulan}

Berdasarkan hasil dan pembahasan dapat disimpulkan bahwa siswa kelas XI jurusan Teknik Desain Pemodelan dan Informasi Bangunan (XI DPIB 1 dan XI DPIB 2) SMK Negeri 2 Jember dapat digolongkan menurut level berpikir geometri van Hiele yaitu level pra visualisasi, visualisasi, analisis, dan deduksi informal. Hasil ketercapaian siswa level pra visualisasi pada tes tingkat berpikir geometri van Hiele sebesar 32,8\% (23 siswa). Siswa level pra visualisasi ini hanya memenuhi lima indikator dari sembilan indikator pada level visualisasi yang dikaitkan dengan tahapan pemecahan masalah Polya dalam memecahkan masalah dimensi tiga. Siswa level pra visualisasi masih belum mampu melewati langkah memahami masalah, menyusun rencana dan melaksanakan rencana dengan baik. Hasil ketercapaian siswa level visualisasi pada tes tingkat berpikir geometri van Hiele sebesar 44,3\% (31 siswa). Siswa level visualisasi telah memenuhi semua indikator (sembilan indikator) pada levelnya yang telah dikaitkan dengan tahapan pemecahan masalah Polya dalam memecahkan masalah dimensi tiga. Hasil ini membuktikan bahwa siswa level visualisasi telah melewati semua langkah dalam tahapan pemecahan masalah Polya dengan baik. Hasil ketercapaian siswa level analisis pada tes tingkat berpikir geometri van Hiele sebesar 12,9\% (9 siswa). Sama halnya dengan siswa level visualisasi, siswa level analisis telah memenuhi semua indikator pada levelnya yang telah dikaitkan dengan tahapan pemecahan masalah Polya dalam memecahkan masalah dimensi tiga. Indikator yang dipenuhi yaitu sebanyak sebelas indikator. Hasil ini membuktikan bahwa siswa level analisis juga telah melewati semua langkah dalam tahapan pemecahan masalah Polya dengan baik. Hasil ketercapaian siswa level deduksi informal pada tes tingkat berpikir geometri van Hiele sebesar 1,4\% (1 siswa). Siswa level deduksi informal tidak memenuhi satu indikator dari tiga belas indikator pada levelnya yang telah dikaitkan dengan tahapan pemecahan masalah Polya dalam memecahkan masalah dimensi tiga. Indikator yang tidak dipenuhi yaitu mempunyai cara lain untuk menyelesaikan masalah. Indikator ini terletak pada langkah melaksanakan rencana. Hasil ini membuktikan bahwa siswa level deduksi informal telah melewati semua langkah dalam tahapan pemecahan masalah Polya dengan baik, namun masih belum mampu menemukan cara lain dalam memecahkan masalah dimensi tiga.

Hasil penelitian berharap dapat menjadi pedoman bagi guru dalam meningkatkan kemampuan berpikir geometri dan pemecahan masalah siswa menjadi lebih baik lagi. Penelitian ini hanya menunjukkan analisis berpikir siswa level pra visualisasi, visualisasi, analisis, dan deduksi informal pada kelas XI jurusan Teknik Desain Pemodelan dan Informasi Bangunan (XI DPIB 1 dan XI DPIB 2) SMK Negeri 2 Jember. Untuk menganalisis yang lebih umum lagi masih diperlukan penelitian lebih lanjut mengenai proses berpikir geometri siswa dalam memecahkan masalah geometri. Oleh karena itu, bagi penelitian selanjutnya diharapkan mampu menganalisis berpikir geometri siswa hingga level deduksi dan rigor yang dalam penelitian ini belum menemukan dan menganalisisnya.

\section{Daftar Pustaka}

Arikunto, P. D. S. (2006). Prosedur Penelitian Suatu Pendekatan Praktik. Jakarta: Rineka Cipta.

Budiman, H. (2015). Analisis Kemampuan Berpikir Geometri Mahasiswa Pendidikan Matematika. Jurnal Prisma, 4(8), 28-40.

Clements, D. H., \& Battista, M. T. (1992). Geometry and Spatial Reasoning. New York: MacMilan.

Firmansyah, F. ., Sunardi, Yudianto, E., \& Ambarwati, R. (2019). The Uniqueness of Viuals Levels in Resolving Geometry of Shape and Space Content based on Van Hieles's Theory. Journal of Physics : Conference Series, 1211(1), 12076. 
Fitriyani, H., Widodo, S. A., \& Hendroanto, A. (2018). Students' Geometric Thinking Based on Van Hiele'S Theory. Infinity Journal, 7(1), 55.

Haviger, J., \& Vojkůvková, I. (2015). The van Hiele Levels at Czech Secondary Schools. Procedia Social and Behavioral Sciences, 171, 912-918. https://doi.org/10.1016/j.sbspro.2015.01.209

Hepytriati. (2014). Profil Kemampuan Berpikir Kritis dan kreatif Siswa Kelas XI IPA SMAN Kota Bengkulu Tahun Ajaran 2013/2014. Universitas Bengkulu.

Hmelo-Silver, C. E., Liu, L., Gray, S., \& Jordan, R. (2015). Using representational tools to learn about complex systems: A tale of two classrooms. Journal of Research in Science Teaching, 52(1), 635. https://doi.org/10.1002/tea.21187

Kemendikbud. (2018). Buku BSE Matematika Kelas XII. Jakarta: Kementerian Pendidikan dan Kebudayaan.

Kirkley, J. (2003). Principles for Teaching Problem Solving: Tachnical Paper \#4. Indiana University: Plato Learning.

Marlina, L. (2013). Penerapan Langkah Ploya dalam Menyelesakan Soal Cerita dan Luas Persegi Panjang. Eektronik Pendidikan Matematika Tadulako, 1, 43-52.

Moleong, L. J. (2012). Metodologi Penelitian Kualitatif. Bandung: PT Remaja Rosdakarya.

Polya, G. (1973). How to Solve It. New Jersey: Princeton University Press.

Polya, G. (1973). How to Solve It: A New Aspect Mathematical Method. Princeton and Oxford: Princeton University Press.

Rawuh. (2009). Geometri Insidensi. Jakarta: Universitas Terbuka.

Reddy, Y. M., \& Andrade, H. (2010). A review of rubric use in higher education. Assessment \& Evaluation in Higher Education, 35(4), 435-448. https://doi.org/10.1080/02602930902862859

Sholihah, S. Z., \& Afriansyah, E. A. (2017). Analisis Kesulitan Siswa dalam Proses Pemecahan Masalah Geometri Berdasarkan Tahapan Berpikir Van Hiele [Penelitian Studi Kasus di Kelas VII SMP Negeri 6 Garut]. Mosharafa, 6(2), 287-298.

Siswono, \& Tatang, Y. E. (2008). Model Pembelajaran Matematika Berbasis Pengajuan dan Pemecahan Masalah untuk Meningkatkan Kemampuan Berfikir Kreatif. Surabaya: UNESA University Press.

Sugiyono. (2016). Metode Penelitian Pendidikan (Pendekatan Kuantitatif, Kualitatif, dan R\&D). Bandung: Alfabeta.

Sukardi. (2011). Metodologi Penelitian Pendidikan (Kompetensi dan Praktiknya). Jakarta: Bumi Aksara.

Sunardi. (2000). Pengembangan Model Pembelajaran Geometri Berbasis Teori Van Hiele. Mathedu: Jurnal Pendidikan Matematika, 1(2), 71-82.

Sunardi, S., \& Yudianto, E. (2015). Antisipasi Siswa Level Analisis Dalam Menyelesaikan Masalah Geometri. AdMathEdu: Jurnal Ilmiah Pendidikan Matematika, Ilmu Matematika Dan Matematika Terapan, 5(2), 203-216.

Thohari, K. (n.d.). Meningkatkan kualitas pembelajaran geometri dengan teori van Hiele (pp. 1-27). pp. 1-27.

Usikin, Z. (1982). Van Hiele Levels and Achievement in Secondary School Geometry. Chicago: The University of Chicago.

Utami, M. W., Setiawan, T. B., \& Oktavianingtyas, E. (2016). Tingkat Berpikir Geometri Siswa Kelas 
VII-B SMP Negeri 1 Jember Materi Segiempat Berdasarkan Teori van Hiele ditinjau dari Hasil Belajar Matematika. Jurnal Edukasi, 3(2), 43-47.

Yudianto, E., Sunardi, Sugiarti, T., Susanto, Suharto, \& Trapsilasiwi, D. (2018). The identification of van Hiele level students on the topic of space analytic geometry. Journal of Physics: Conference Series, 983(1), 1-5. https://doi.org/10.1088/1742-6596/983/1/012078 